\title{
Evidence for Allee effects in an over-harvested marine gastropod: density-dependent mating and egg production
}

\author{
Allan W. Stoner*, Melody Ray-Culp** \\ Caribbean Marine Research Center, Lee Stocking Island Field Station, Exuma Cays, Bahamas
}

\begin{abstract}
Conservation programs often focus on studying extinction risks encountered by small populations and determining minimum population sizes below which they cannot recover. In certain cases, per capita rates of population growth become negative at low population density. This 'Allee effect' (or 'depensation') is rarely considered in marine systems. We conducted surveys of adult density, reproductive behavior, and spawning in natural populations of Caribbean queen conch Strombus gigas at 2 locations in the Exuma Cays, Bahamas, to test for Allee effects. Mating never occurred when density was $<56$ conch ha ${ }^{-1}$, and spawning never occurred at $<48$ conch ha ${ }^{-1}$, clearly demonstrating the operation of depensatory mechanisms. Reproductive behavior then increased rapidly to asymptotes at densities near 200 conch ha ${ }^{-1}$. Heavily exploited populations of queen conch in the Caribbean have been slow to recover despite fishery closures. Failure to recover could result from spawning stock densities that are reduced to the point at which Allee effects begin to operate on reproductive behavior.
\end{abstract}

KEY WORDS: Conservation - Depensation - Fisheries management $\cdot$ Reproduction $\cdot$ Spawning $\cdot$ Strombus gigas

Resale or republication not permitted without written consent of the publisher

The traditional logistic equation for population growth predicts that per capita growth will increase with decreasing population abundance because of reduced competitive interactions. Sustainable stock exploitation is possible because of this compensatory mechanism. However, individuals often benefit from the presence of conspecifics and there can be positive effects of density (Allee effects), particularly at low

Present addresses:

*Fisheries Behavioral Ecology Program, Alaska Fisheries Science Center, NOAA, National Marine Fisheries Service, 2030 S. Marine Science Dr, Newport, Oregon 97365, USA. E-mail: al.stoner@hmsc.orst.edu

**The Environmental Learning Center, 255 Live Oak Dr, Vero Beach, Florida 32963, USA population size. Negative rates of per capita growth (depensation) can occur below a critical population size or density. Among the mechanisms that affect measurable components of individual fitness are antipredator aggression, predator swamping, and social facilitation of reproduction (Stephens \& Sutherland 1999). Although Allee effects are best known in highly social and cooperative animals, they also occur when the only form of contact with conspecifics is for sexual reproduction (McCarthy 1997, Couchamp et al. 1999).

There is abundant evidence of poor survivorship and reproduction in mammals and other terrestrial fauna reduced to small populations (Courchamp et al. 1999, Stephens \& Sutherland 1999), but until recently, Allee effects have rarely been considered for populations of marine organisms. There is now good experimental evidence that fertilization success in urchins increases with spawner density (Levitan 1991, Levitan et al. 1992). Evidence for Allee effects in marine fishes continues to be a subject of debate (Myers et al. 1995, Liermann \& Hilborn 1997, Shelton \& Healey 1999). There is, and should be, an increasing interest in Allee effects because of relevance to issues of species extinctions, conservation, fisheries management, and stock rehabilitation (Frank \& Brickman 2000).

In this study, we tested the hypothesis that Allee effects occur in populations of queen conch Strombus gigas, a large motile gastropod that supports one of the most important marine fisheries in the Caribbean region (Berg \& Olsen 1989, Stoner 1997). The species has been over-harvested throughout much of its geographic range, and diverse stock management regulations have been in place in Caribbean nations since the 1980s (Appeldoorn 1994). While the queen conch is not currently threatened with extinction, it has been listed for more than a decade in Appendix II of the Convention of International Trade in Endangered Species 
(CITES), which includes species at risk and regulates commercial harvest and export. Complete closures of the fishery in Florida in 1986 (Berg et al. 1992a, R. Glazer unpubl. data) and Bermuda in 1978 (Berg et al. 1992b) have not resulted in stock recoveries. Allee effects in queen conch were predicted by Appeldoorn (1988a) on the basis of strombid reproductive biology and behavior, and could have important implications for fisheries management.

The queen conch is an ideal subject species for analysis of depensatory reproductive mechanisms. Adult populations are easily surveyed because of their large size (to $>30 \mathrm{~cm}$ shell length) and slow movement (probably $<100 \mathrm{~m} \mathrm{~d}^{-1}$ ) (authors' pers. obs., R. Glazer unpubl. data). The species is gonochoristic, sex ratio is typically $1: 1$, and fertilization is internal. Copulation lasts for at least several hours, spawning requires 24 to $36 \mathrm{~h}$, and egg masses are large (to $\sim 12 \mathrm{~cm}$ ) and easily observed (D'Asaro 1965, Davis et al. 1984, Stoner et al. 1992). Individual fecundity is largely independent of age after maturity, because somatic growth ceases at sexual maturity (Appeldoorn 1988b). Females lay 7 to 9 egg masses

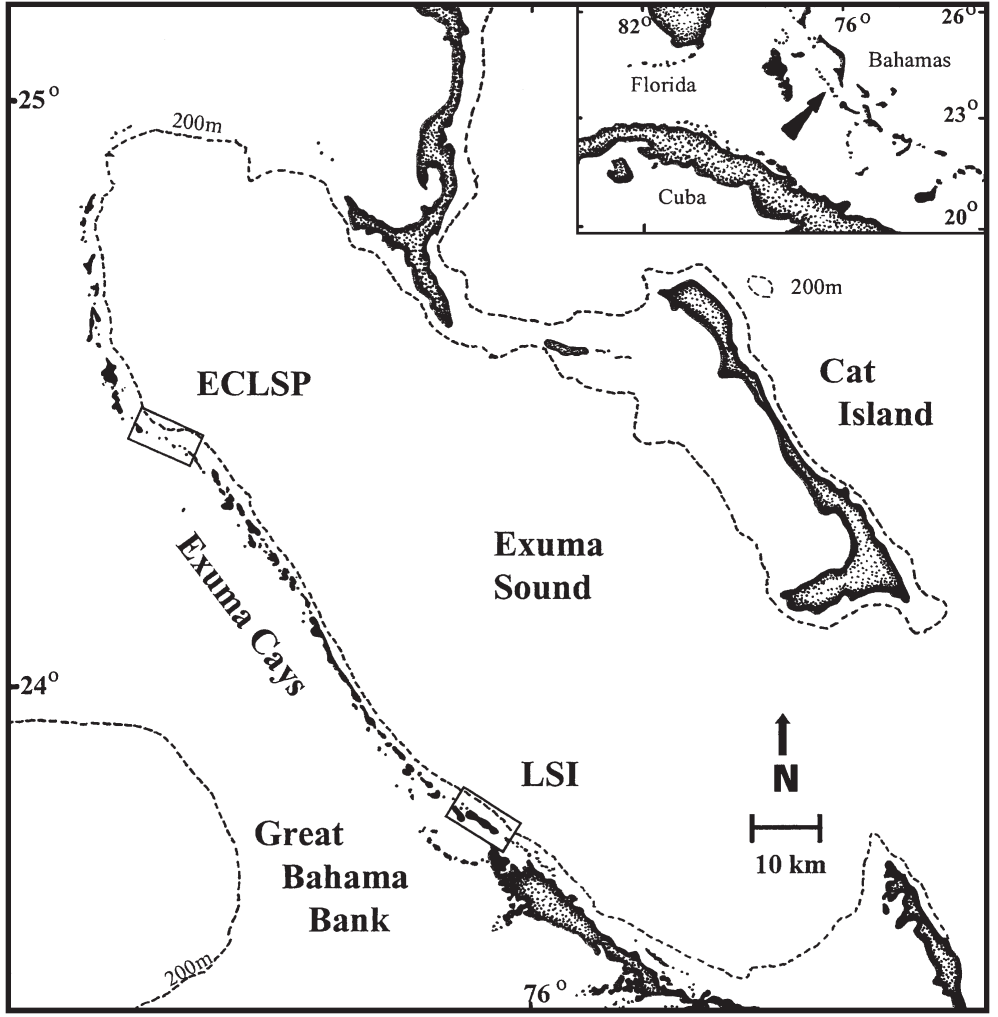

Fig. 1. Map of Exuma Sound, central Bahamas, showing the 2 locations where reproductive surveys were conducted for Strombus gigas in the Exuma Cays Land \& Sea Park (ECLSP) and near Lee Stocking Island (LSI) during the warm reproductive season, each egg mass holds several hundred thousand eggs, eggs hatch in 3 to $5 \mathrm{~d}$, and the larvae are planktonic for 2 to 4 wk (Randall 1964, Davis et al. 1984). In the Bahamas, adult queen conch move onto homogeneous expanses of sand during the summer to spawn, and little or no feeding occurs during the spawning season (Stoner \& Sandt 1992) (see 'Methods').

Appeldoorn (1988a) hypothesized that depensation would occur in strombid gastropods because of limited ability to locate mates at low density, and because contact with males might stimulate gametogenesis in females. The latter hypothesis was based upon the fact that mating in Strombus costatus (milk conch) was more frequent in spawning than in non-spawning females. In this study we conducted intensive field surveys over a wide range of queen conch densities to test the null hypothesis that mating and spawning are independent of adult density.

Methods. The reproductive season for queen conch in the Exuma Cays, Bahamas, extends from at least April through September, with maximum mating and spawning in June, July, and August (Stoner et al. 1992). Observations for this investigation were made during a $17 \mathrm{~d}$ period in the middle of the reproductive season (12 to 29 July 1995) to minimize the potential for temporal variation in reproductive behavior. Rough weather can inhibit reproduction in conch (Stoner et al. 1992), but conditions were relatively mild during the study period.

Surveys of adult queen conch were conducted in the Exuma Cays near Lee Stocking Island and in the center of the Exuma Cays Land \& Sea Park (Fig. 1). The 2 sites are $\sim 70 \mathrm{~km}$ apart. Lee Stocking Island, location of the Caribbean Marine Research Center field station, has been the site of numerous queen conch investigations including studies on adult migration and spawning activity (Stoner \& Sandt 1992, Stoner et al. 1992). The Exuma Cays Land \& Sea Park extends for $40 \mathrm{~km}$ along the Exuma Cays and is protected as a no-take fishery reserve. Density of conch in the Park is unusually high (to $>200$ conch ha ${ }^{-1}$ ) compared with populations in other parts of the geographic range in recent years (Stoner \& Ray 1996). While adult conch are present from the intertidal zone to $>30 \mathrm{~m}$ depth in the Exuma Cays, our experience at the 2 sites has revealed that maximum reproductive activity occurs in the depth range of 10 to $20 \mathrm{~m}$ on bare-sand habitat with shallow sand waves (height $<10 \mathrm{~cm}$ ) (Stoner \& Sandt 
1992, authors' pers. obs.). Therefore, the surveys for this study were concentrated in this habitat type (at 11 to $19 \mathrm{~m}$ depth; mean = $12 \mathrm{~m}$ ), reducing the probability that environmental factors other than conch density influenced reproductive behavior. Lack of feeding during the reproductive season also reduced the potential for spatial variation in the behavioral categories quantified.

Surveys were conducted by scuba diving at widely dispersed sites in each of the 2 locations (i.e., in the aforementioned habitat type) to provide observations on reproductive behavior over a broad range of conch densities. As it became apparent early in the study that reproductive behavior reached an asymptote at densities $<200$ conch ha ${ }^{-1}$, we increased our effort to survey sites in the lower density range. The density of adult conch was determined at each dive site by counting all conch within 3 closely spaced but non-overlapping circles (20 m radius) arranged in a triangular pattern. This strategy was employed to facilitate surveys of the largest possible area, where bottom time for the divers was limited, and to reduce heterogeneity in population density. The reproductive activity of each conch was classified as in Stoner et al. (1992): (1) copulating; (2) pairing - when the shells of 2 individuals were touching and in the mating position but copulation was not occurring; (3) spawning - when eggs were being extruded by the female; and (4) non-reproductivewhen none of the 3 other behavioral types were observed. Females that were simultaneously copulating and laying eggs were classified as spawning, and the male was classified as copulating. Ultimately, pairing and copulating were combined for analysis under the term mating. The relatively few unattended egg masses found in the surveys were not counted because these could have been laid as much as a week earlier. Few juvenile conch (i.e., those without a flared shell lip, see Appeldoorn 1988b) were encountered in the survey $(<1 \%$ of total count), and these were not considered in density estimates.

Preliminary analysis showed that pooling data from the density circles, and the resulting survey scale of $\sim 1$ ha provided a reproducible estimate of conch density. At low-density sites there were relatively few conch in the survey plots. In such cases, all additional bottom time available to the divers was spent searching for additional conch to supplement quantification of reproductive behavior. Percentages of the different reproductive types were calculated on the basis of all conch observed at the site. However, only individuals counted in the circles were used to calculate density. For analysis, we used no surveys with less than 10 conch observed at the dive site. The modal count for the entire survey was 48 conch (mean $=73$, range $=$ 10 to $351, \mathrm{n}=54$ ).
Density-dependence in behavioral response was examined using the approach of Myers et al. (1995), where the Beverton-Holt relationship was modified to include a parameter $(\delta)$ allowing for a depensatory mechanism:

$$
R=\left(\alpha S^{\delta}\right) /\left[1+\left(S^{\delta} / k\right)\right]
$$

$R$ is the reproductive metric (spawning, mating), $S$ is spawner density, and $\alpha, \delta$, and $k$ are the parameters for the non-linear function. In the original Beverton-Holt equation, $R$ represented 'recruitment'. We do not propose equating reproductive behavior with recruitment in this study, but simply test for depensatory mechanism with the well-known mathematical expression. When $\delta=1$, the equation defines a simple inverse exponential function. The function becomes increasingly sigmoid with increasing values of $\delta>1$; therefore, $\delta$ is an index of depensation (see Myers et al. 1995). Curve fitting was accomplished with the statistical program Stata (StataCorp 1999), and significance of $\delta$ was tested with the likelihood ratio between the fitted model and a model with $\delta$ fixed at 1.0 .

Results. Fifty-four sites were visited during the $17 \mathrm{~d}$ survey period. Mean densities ranged from 2 to 812 conch $\mathrm{ha}^{-1}$, except at 1 dive site where density was 2793 conch ha ${ }^{-1}$. This site was excluded from statistical analysis and graphics. While up to $33 \%$ of adults were typically observed in some form of reproductive behavior (i.e., mating and/or spawning) (Fig. 2A), there was an obvious threshold of density required for reproduction. No mating behavior whatsoever was observed at dive sites with densities $<56$ conch ha ${ }^{-1}$ (Fig. 2B) ( $20.7 \%$ of all sites), and no spawning was observed where density was $<48$ conch ha ${ }^{-1}$ (Fig. 2C) $(22.6 \%$ of sites). It is also clear that reproduction reached an asymptotic level near 200 conch ha ${ }^{-1}$, perhaps at lower densities for spawning. Mating and spawning frequencies at the 1 dive site with extremely high density (2793 conch $\mathrm{ha}^{-1}$ ) were 34.5 and $6.3 \%$, respectively. Points for Lee Stocking Island and the Exuma Park were thoroughly interspersed, suggesting that the relationships were not site dependent (Fig. 2). Curve fitting resulted in highly significant correlation coefficients $(\mathrm{p}<0.0001)$ for all 3 of the reproductive metrics. And, significant $\delta$ terms (Fig. 2) provide statistical evidence in support of the obvious Allee effects. Asymptotic $95 \%$ confidence intervals for $\delta$ were 2.24 to 4.85 for total reproductive behavior, 1.13 to 3.21 for mating, and 4.79 to 5.76 for spawning. Correlation coefficients and the distributions of residuals associated with the curvilinear equations were always superior to those for linear models because of the apparent density thresholds for reproduction.

Discussion and conclusions. Reproductive rates in queen conch can be influenced by a variety of factors 


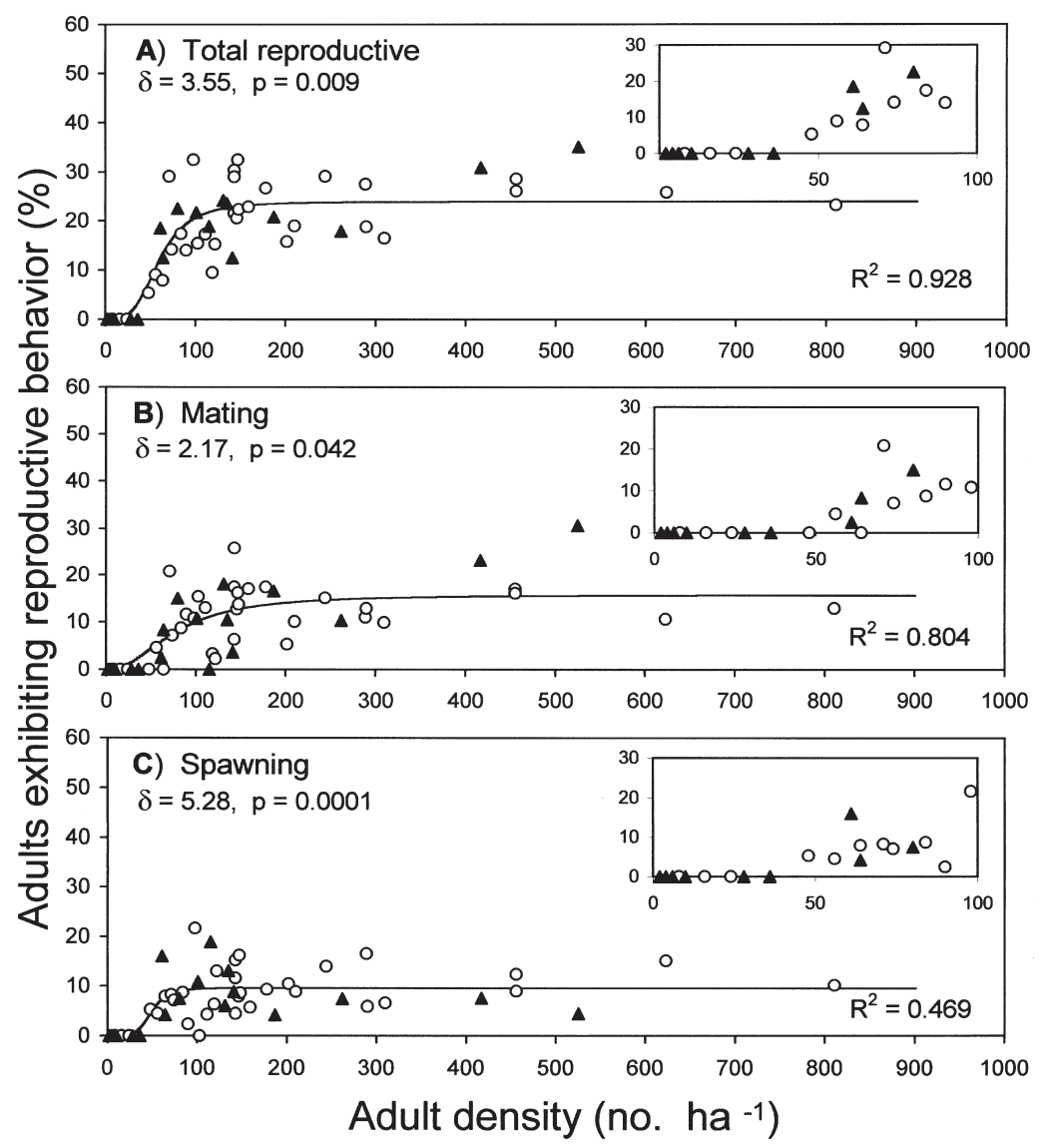

Fig. 2. Strombus gigas. Reproductive behavior shown as a function of adult density. Total reproductive: percentage of adult queen conch engaged in all forms of reproductive behavior. $\delta$ : coefficient describing the depensatory parameter in the non-linear curves fit to the data (see text for explanation). $\mathrm{p}$ : significance level for $\delta$, and all of the correlation coefficients $\left(\mathrm{R}^{2}\right)$ are highly significant $(\mathrm{p}<0.0001)$. Two study sites are represented: $O=$ Exuma Cays Land \& Sea Park $(n=35), \boldsymbol{\Delta}=$ Lee Stocking Island $(n=18)$. Insets show detail for the left side of each plot (density < 100)

including temperature, photoperiod, wave surge, and habitat features such as sediment grain-size and bed forms (Stoner \& Sandt 1992, Stoner et al. 1992). However, in this study, where all effort was made to standardize these variables, our observations reveal that conch populations could be strongly influenced by Allee effects. There were sigmoid relationships between adult density and metrics of reproductive behavior. Even stronger evidence for Allee effect was provided by the complete absence of mating or spawning behavior at densities $<56$ and 48 conch $\mathrm{ha}^{-1}$, respectively. Courchamp et al. (1999) suggested that intraspecific interactions contributing to an Allee effect can range from strict cooperation to unconscious facilitation. We have observed no social behavior in adult queen conch, apart from some degree of aggregation occurring during the summer reproductive season, and conclude that the absence of reproduction in low-density populations is related primarily to encounter rate. Queen conch are substantially more motile than many gastropods, but recent tracking of adult queen conch with ultrasonic tags in the Florida Keys has shown that daily movements were just 2 to $15 \mathrm{~m}$, and annual home ranges were 2 to 30 ha (R. Glazer pers. comm.). McCarthy (1997) proposed that the probability $(p)$ of encountering a mate in a randomly distributed population could be calculated on the basis of mate density $(m)$ and the area effectively searched $(S)$ in some unit of time, where $p=1-\mathrm{e}^{-m S}$. Using this algorithm and a liberal estimate of search area for a male queen conch at $50 \mathrm{~m}^{2} \mathrm{~d}^{-1}$, probability of encountering a female during any one day would be $<0.2$ up to a density of $\sim 50$ female conch ha ${ }^{-1}$. The actual relationship is probably more complicated because male strombids may follow the trails of females (authors' pers. obs.); however, female conch are not always receptive to mating. If encounters with males stimulate gametogenesis in female conch, as postulated by Appeldoorn (1988a), the Allee effect on reproductive output would be intensified. This mechanism remains untested.

Although Allee effects were evident only at the lowest densities of conch observed in this study $\left(<50\right.$ conch ha $\left.{ }^{-1}\right)$, most populations in the greater Caribbean region are now within the range where negative population growth is a significant risk. Highest densities of adult conch were reported from the earliest systematic surveys in the 1970s. Alcolado (1976) observed 1582 conch ha ${ }^{-1}$ at 1 site in Cuba in 1972/74, and Hesse (1979) reported 255 conch ha ${ }^{-1}$ in the Turks and Caicos Islands in 1974/75. In Islas Los Roques, Venezuela, densities in unfished locations were 1886 conch ha ${ }^{-1}$ and 160 conch $\mathrm{ha}^{-1}$ in fished areas in 1981/83 (Weil \& Laughlin 1984), but even these substantial populations were dramatically reduced by fishing in the latter part of the 1980s (Rodríguez \& Posada 1994). Despite complete closure of the fishery in Florida in 1986, adult densities in the Florida Keys remain near 0.5 conch ha ${ }^{-1}$ (Berg et al. 1992a, R. Glazer pers. comm.). Berg et al. (1992b) found just 3.3 conch ha ${ }^{-1}$ on the reef flat in Bermuda in 1989, and the only reproductive behavior observed was in 5 apparent aggregations of unreported density. 
When Friedlander et al. (1994) surveyed 13 locations in the US Virgin Islands between 1981 and 1990, average densities of adult conch decreased from 38 to 11 conch $\mathrm{ha}^{-1}$. Highest densities were 20 to $56 \mathrm{conch} \mathrm{ha}^{-1}$ and all others were $<9 \mathrm{conch} \mathrm{ha}^{-1}$. In the heavily fished waters of Puerto Rico, densities were $<0.1$ conch ha ${ }^{-1}$ at all depth intervals to $30 \mathrm{~m}$ in 1985/86 (Torres-Rosado 1987). According to our findings in the Exuma Cays, most of these populations would produce no progeny, and recruitment would depend upon upstream sources (Stoner 1997, Stoner et al. 1997).

It remains to be learned exactly what methods and spatial scale will be most appropriate for assessing reproductive populations. In the Bahamas, queen conch make seasonal reproductive migrations between feeding and reproductive grounds (Stoner \& Sandt 1992); consequently surveys during the summer spawning season are likely to be most useful. Also, spawners appear to concentrate in particular locations or habitats (Berg et al. 1992b, Glazer \& Anderson unpubl. data), especially in the final stages of local extinction. Critical spawning sites must be identified and protected, and assessed individually because they represent the effective spawner populations.

Conch populations in most nations are now probably at or near densities where Allee effects present a serious obstacle to stock recovery. Exceptions to this may be where there are strict management plans that preserve reproductive stock structure. The most comprehensive and current data are available for fished and unfished areas in the Exuma Cays, Bahamas, and at least 2 management strategies appear to be effective. First, legal fishing for conch in the Bahamas is limited to free-diving and limited use of surface-supply air (hookah system). This gear restriction provides a refuge for spawners in depths greater than $\sim 10 \mathrm{~m}$ at Lee Stocking Island (Stoner \& Schwarte 1994). A second important strategy is implementation of areas closed to fishing. Conch were significantly more dense in the Exuma Cays Land \& Sea Park than at Lee Stocking Island in all depth intervals ( $>100$ conch ha ${ }^{-1}$ at depths $>10 \mathrm{~m}$ ). The difference was particularly high on the shallow bank (1 to $4 \mathrm{~m}$ ) west of the islands (53.6 conch ha ${ }^{-1}$ in the Park, 1.7 conch ha ${ }^{-1}$ at Lee Stocking Island) (Stoner \& Ray 1996). While reproductive behavior was not quantified in the comparative survey, mating and spawning were common in the Park, even on the bank where adult density just exceeded the apparent threshold for reproduction. Given the very large surface area of shallow-water habitat in the Bahamas and other nations with extensive bank systems, reproduction by shallow-water populations must have contributed enormous larval production prior to human exploitation of the conch resource.
In the present study, mating and spawning reached asymptotic levels at densities well below those commonly reported for undisturbed natural populations; therefore, it is likely that fisheries for queen conch can be sustained by compensatory mechanisms. However, conch are easily harvested over their entire depth range ( 0 to $35 \mathrm{~m}$ ) by divers using scuba, and reductions of population density below the reproductive threshold ( $\sim 50$ conch ha $\left.{ }^{-1}\right)$ is nearly guaranteed without gear restrictions or closed areas. Seasonal closures and size limitations will have little benefit if adult density is reduced to the level at which depensatory mechanisms occur. Rehabilitation of a stock below critical density might be improved by enhancing local adult densities by transplanting to reduce Allee effects, but there are a host of difficulties associated with stock enhancement (Stoner 1994, Blankenship \& Leber 1995, Grimes 1998). Furthermore, recruitment would depend upon retention of larvae and survival of juveniles in appropriate nursery habitats.

An increasing number of marine species are heavily exploited or threatened with extinction (Norse 1993); consequently, there is an increasing need to understand the performance of populations at low population density (Couchamp et al. 1999, Stephens \& Sutherland 1999, Frank \& Brickman 2000). Vulnerability of animal populations to overexploitation depends upon their reproductive behavior and mating systems (Vincent \& Sadovy 1998). However, the observed cases of depensation in marine systems include 3 major phyla and species with both internal and external fertilization (Levitan et al. 1992, Myers et al. 1995, Liermann \& Hilborn 1997, this study), and Allee effects may be widespread taxonomically. Given the extreme ecological and economic consequences of not considering depensatory mechanisms in fisheries management and other conservation practices, it will be critically important to avoid Type II errors related to Allee effects (i.e., where a conclusion of no effect is made when one does exist).

Acknowledgements. This research was supported by grants from the National Undersea Research Program of NOAA (US Department of Commerce) and the Shearwater Foundation (New York). Critical logistical and diving support was provided by the Caribbean Marine Research Center, especially Brian Kakuk, the Lee Stocking Island diving safety officer. Divers included E. Bartels, T. Hall, L. Hambrick, R. Jones, C. Kuiken, J. Lin, N. Mehta and K. Noyes. F. Scharf provided statistical assistance and J. Pessutti produced the graphics. C. Meise, J. Manderson, and 2 anonymous reviewers provided helpful comments on the manuscript.

\section{LITERATURE CITED}

Alcolado PM (1976) Crecimiento, variaciones morfológicas de la concha y algunas datos biológicos del cobo Strombus 
gigas L. (Mollusca, Mesogastropoda). Acad Cienc Cuba Ser Oceanol 34:1-36

Appeldoorn RS (1988a) Fishing pressure and reproductive potential in strombid conchs: is there a critical stock density for reproduction? Mem Soc Cienc Natur La Salle 48: 275-288

Appeldoorn RS (1988b) Age determination, growth, mortality, and age of first reproduction in adult queen conch, Strombus gigas L., off Puerto Rico. Fish Res 6:363-378

Appeldoorn RS (1994) Queen conch management and research: status, needs and priorities. In: Appeldoorn R, Rodríguez B (eds) Queen conch biology, fisheries and mariculture. Fund Cient Los Roques, Caracas, p 301-319

Berg CJ Jr, Olsen DA (1989) Conservation and management of queen conch (Strombus gigas) fisheries in the Caribbean. In: Caddy JF (ed) Marine invertebrate fisheries: their assessment and management. Wiley, New York, p 421-442

Berg CJ, Glazer R, Carr J, Krieger J, Acton S (1992a) Status of the queen conch, Strombus gigas, in Florida waters. Proc Gulf Caribb Fish Inst 41:439-443

Berg C, Ward J, Luckhurst B, Nisbet K, Couper F (1992b) Observations of breeding aggregations of the queen conch, Strombus gigas, in Bermuda. Proc Gulf Caribb Fish Inst 42:161-171

Blankenship HL, Leber KM (1995) A responsible approach to marine stock enhancement. Am Fish Soc Symp 15:167-175

Courchamp F, Clutton-Brock T, Grenfell B (1999) Inverse density dependence and the Allee effect. Trends Ecol Evol 14:405-410

D'Asaro CN (1965) Organogenesis, development and metamorphasis in the queen conch, Strombus gigas, with notes on the breeding habits. Bull Mar Sci 15:359-416

Davis M, Mitchell BA, Brown JL (1984) Breeding behavior of the queen conch Strombus gigas Linné held in a natural enclosed habitat. J Shellfish Res 4:17-21

Frank KT, Brickman D (2000) Allee effects and compensatory population dynamics within a stock complex. Can J Fish Aquat Sci 57:513-517

Friedlander A, Appeldoorn RS, Beets J (1994) Spatial and temporal variations in stock abundance of queen conch, Strombus gigas, in the US Virgin Islands. In: Appeldoorn R, Rodríguez B (eds) Queen conch biology, fisheries and mariculture. Fund Cient Los Roques, Caracas, p 51-60

Grimes CB (1998) Marine stock enhancement: sound management or techno-arrogance? Fisheries 23(9):18-23

Hesse KO (1979) Movement and migration of the queen conch Strombus gigas in the Turks and Caicos Islands. Bull Mar Sci 29:303-311

Levitan DR (1991) Influence of body size and population density on fertilization success and reproductive output in a free-spawning invertebrate. Biol Bull 181:261-268

Levitan DR, Sewell MA, Chia FS (1992) How distribution and abundance influence fertilization success in the sea urchin Strongylocentrotus franciscanus. Ecology 73:248-254

Liermann M, Hilborn R (1997) Depensation in fish stocks: a hierarchic Bayesian meta-analysis. Can J Fish Aquat Sci 54:1976-1984

McCarthy MA (1997) The Allee effect, finding mates and theoretical models. Ecol Model 103:99-102

Editorial responsibility: John Lawrence (Contributing Editor), Tampa, Florida, USA
Myers RA, Barrowman NJ, Hutchings JA, Rosenberg AA (1995) Population dynamics of exploited fish stocks at low population levels. Science 269:1106-1108

Norse EA (1993) Global marine biological diversity: a strategy for building conservation into decision making. Island Press, Washington, DC

Randall JE (1964) Contributions to the biology of the queen conch Strombus gigas. Bull Mar Sci 14:246-295

Rodríguez B, Posada J (1994) Revisión histórica de la pesquería del botuto o guarura (Strombus gigas L.) y el alcance de su programa de manejo en el Parque Nacional Archipiélago de Los Roques, Venezuela. In: Appeldoorn R, Rodríguez B (eds) Queen conch biology, fisheries and mariculture. Fund Cient Los Roques, Caracas, p 13-24

Shelton PA, Healey BP (1999) Should depensation be dismissed as a possible explanation for the lack of recovery of the northern cod (Gadus morhua) stock? Can J Fish Aquat Sci 56:1521-1524

StataCorp (1999) Stata Statistical Software: Release 6.0. College Station, TX

Stephens PA, Sutherland WJ (1999) Consequences of the Allee effect for behaviour, ecology and conservation. Trends Ecol Evol 14:401-405

Stoner AW (1994) Significance of habitat and stock pretesting for enhancement of natural fisheries: experimental analyses with queen conch. J World Aquacult Soc 25: 155-165

Stoner AW (1997) The status of queen conch, Strombus gigas, research in the Caribbean. Mar Fish Res 59(3):14-22

Stoner AW, Ray M (1996) Queen conch, Strombus gigas, in fished and unfished locations of the Bahamas: effects of a marine fishery reserve on adults, juveniles, and larval production. Fish Bull 94:551-565

Stoner AW, Sandt VJ (1992) Population structure, seasonal movements and feeding of queen conch, Strombus gigas, in deep-water habitats of the Bahamas. Bull Mar Sci 51: $287-300$

Stoner AW, Schwarte KC (1994) Queen conch, Strombus gigas, reproductive stocks in the central Bahamas: distribution and probable sources. Fish Bull 92:171-179

Stoner AW, Sandt VJ, Boidron-Metairon IF (1992) Seasonality of reproductive activity and abundance of veligers in queen conch, Strombus gigas. Fish Bull 90:161-170

Stoner AW, Mehta N, Lee TN (1997) Recruitment of Strombus veligers to the Florida Keys reef tract: relation to hydrographic events. J Shellfish Res 16:1-6

Torres-Rosado ZA (1987) Distribution of two mesogastropods, the queen conch, Strombus gigas Linnaeus, and the milk conch, Strombus costatus Gmelin, in La Pargueera, Lajas, Puerto Rico. MSc thesis, University Puerto Rico, Mayaguez

Vincent A, Sadovy Y (1998) Reproductive ecology in the conservation and management of fishes. In: Caro $\mathrm{T}$ (ed) Behavioral ecology and conservation biology. Oxford University Press, Oxford, p 209-245

Weil E, Laughlin R (1984) Biology, population dynamics, and reproduction of the queen conch, Strombus gigas Linne, in the Archipelago de Los Roques National Park. J Shellfish Res 4:45-62

Submitted: January 20, 2000; Accepted: June 10, 2000

Proofs received from author(s): July 28, 2000 